\title{
CORRIGENDUM
}

\section{Peroxiredoxin 2 specifically regulates the oxidative and metabolic stress response of human metastatic breast cancer cells in lungs}

V Stresing, E Baltziskueta, N Rubio, J Blanco, MC Arriba, J Valls, M Janier, P Clézardin, R Sanz-Pamplona, C Nieva, M Marro,

D Petrov and A Sierra

Oncogene (2013) 32, 804; doi:10.1038/onc.2012.473

Correction to: Oncogene (2013) 32, 724-735; doi:10.1038/

onc.2012.93; published online 19 March 2012

Since the publication of the above manuscript, the authors have identified an error in the author list; the name of the twelfth author was incorrectly presented. The corrected author list is shown above.

\section{RETRACTION}

\section{Promoter hypomethylation of the LINE-1 retrotransposable elements activates sense/antisense transcription and marks the progression of chronic myeloid leukemia}

J Roman-Gomez, A Jimenez-Velasco, X Agirre, F Cervantes, J Sanchez, L Garate, M Barrios, JA Castillejo, G Navarro, D Colomer, F Prosper, A Heiniger and A Torres

Oncogene (2013) 32, 804; doi:10.1038/onc.2012.592

Retraction to: Oncogene (2005) 24, 7213-7223; doi:10.1038/ sj.onc.1208866; published online 19 September 2005

The authors wish to retract the November 3, 2005, paper cited above. Figure $6 \mathrm{a}$ in the published manuscript was inappropriately reproduced from figure 1 in a previously published paper from Rosas SL, Koch W, da Costa Carvalho MG, Wu L, Califano J, Westra W, Jen J, Sidransky D. Promoter hypermethylation patterns of p16, O6-methylguanine-DNA-methyltransferase, and death-associated protein kinase in tumors and saliva of head and neck cancer patients. Cancer Research 61, 939-942, 1 February 2001. The manipulation of the figure was performed by Dr RomanGomez. None of the other authors were involved in or were aware of these events. The authors apologize to the readers, reviewers, and editors of Oncogene for publishing this erroneous image. All the authors agree to the retraction except Dr Roman-Gomez. 